\begin{tabular}{cc}
\hline \hline 特集 & 内視 鏡一 \\
& 最近の進歩 \\
\hline
\end{tabular}

順天堂医学 39 (1)

P. $32 \sim 38(1993)$

\title{
内視鏡的泌尿器科学（Endourology）の進歩 **
}

Recent advances in endourology

\author{
藤 目真 $*$ \\ MaKoto FUJIME, M.D.
}

䎵尿器科における内視鏡の現況についてで紹介するために, 三つの疾患を取り上げてみました。 現在米国では前立腺肥大症に対する手術はほとんどが内視鏡手術（TUR）で行われておりま す. わが国においても近年 TUR の普及は目覚ましく, 前立腺肥大症手術の 9 割以上が TUR である施設も少なくありません. CCD カメラの開発は, 複数の医師が同時に手術の進行を監視 するてとを可能とし, TUR の安全性と教育の向上とに役立っています.

また尿路結石の治療においても過去 10 年程の間に大きな進歩がみられ，現在では開腹手術が 行われることはほとんどなくなりました。体外式衝撃波結石破砕や, 腎孟鏡・尿管鏡などの内 視鏡下にレーザー・超音波・衝撃波などによる結石破砕が，全国的に行われております。

泌尿器科領域における腹胫鏡の応用は, 比較的歴史の浅い分野ですが, 男性不妊の原因の一 つである精索静脈瘤に対する内精静脈結禁術は, 腹腔鏡手術の最も良い適応の一つであると思 われます。
キーワード：内視鏡手術, 前立腺肥大症, 尿路結石症, 精索静脈瘤
Key words : endoscopic surgery, benign prostatic hypertrophy, urolithiasis, varicocele

\section{はじめに}

泌尿器科と内視鏡との関わりは歴史的にも深い ものがあります. 泌尿器科学の歴史は, ある意味 で内視鏡の歴史と言っても過言ではありません. Nitze が初めて膀胱鏡を作ったのは1877年で, 今 から100年以上も前のてとでした。それ以後ての 内視鏡の臨床応用の拡大が, 泌尿器科の独自性を 形成する重要な柱の一つとなりました.1897年に

* 順天堂大学医学部泌尿器科学講師

Department of Urology, Juntendo University School of Medicine, Tokyo, Japan

$* *$ 第263回順天堂医学会学術集会〔N ov. 21, 1992 開催 (Dec. 15，1992受付)
Albarran がいわゆる Albarran 桿子を作ってか ら，尿管カテーテリスムスなど検查への応用がす すんだほか, 1908年には Young の砕石器が開発 され, 膀胱結石の摘出や破砕また膀胱内異物の除 去といった治療面への応用も比較的早い時期から 行われてきました，そして1931年に McCarthy によって Stern-McCarthy 切除鏡が開発される におよんで, 膀胱腫瘍や前立腺肥大症の内視鏡手 術が可能となりました。，その後1970年代までに英 国の眼科医 Hopkins のロッドレンズの開発 （1966）や, 高輝度光源の発達, グラスファイバー ライトガイドの導入などによって, 硬性内視鏡の 性能は飛躍的に向上しました。

しかしててまでの泌尿器科内視鏡の歴史は, そ の対象が膀胱および尿道に限られていたためその 
後の発展に比べれば, 比較的穏やかな進歩を遂げ た時代と言えます。と乙ろが1980年代に入って上 部尿路結石の治療を主な目的として, 硬性および 軟性腎孟鏡尿管鏡が急速に普及し, また1990年代 に入っては腹腔鏡手術の導入も盛んとなり，わず か10年程の間に泌尿器科における内視鏡の応用範 囲は著しく拡大しました。乙の目まぐるしいまで の変化によって, 今や腎皿内や尿管内が内視鏡下 に直接観察できるようになったのは勿論のこと, 手術的操作も可能であり, 一方では腹腔鏡下に, 腎摘除術や前立腺全摘術まで試みられる時代とな りました．ご存じのように尿路は腹膜外の臓器で すが, 一部では後腹膜鏡の開発も行われており, 近い将来には泌尿器外科力゙内視鏡外科に変身する 日がやって来るかもしれません．

このような激しい潮流の原動力となっているも のは, 単に一部の医者の冒険心や功名心ではなく, それは単なるきっかけに過ぎず, むしろ患者サイ ドの minimally invasive surgery, さらには no surgery への強い願望ではないかと思われます。 したがってての大きな流れは, その適応において 将来縮小するてとはあっても, 決して止むてとは ないと思われます．乙のような背景の上にたって, こてでは過去10年間の急激な変化を踏まえながら, 泌尿器科における内視鏡の現況について, 三つの 疾患を取り上げてで紹介したいと思います。

\section{膀胱尿道切除鏡〔前立腺肥大症の治療〕}

1925年に Stern がループ電極を用いた最初の 電気切除鏡を考案し, 1931年には McCarthy が 切除装置に改良を加えて前斜視鏡を用いた SternMcCarthy 式切除鏡を完成させました。乙れが高 周波電流を用いた近代的内視鏡手術・経尿道的切 除術（TUR）の始めであります．その後, TUR の普及は比較的ゆっくりと進み, 1950年代に米国 で, ついでヨーロッパ・アジアへと広がっていき, 1950年代の末頃にはわが国でも TUR が行われる ようになりましたが，1970年代から1980年代になっ て広く普及するようになりました。 そして1990
年代に入った今日では, 欧米では前立腺肥大症に 対して開腹手術が行われることは稀であり, わが 国においても, 前立腺肥大症手術の 9 割以上が $\mathrm{T}$ UR である施設が少なくない状況で, TUR は前 立腺肥大症治療の主役となっております。

前立腺肥大症は一般に50歳以降の男性にみられ る疾患で, 原因は判っていませんが前立腺のうち 内腺之呼ばれる部分が大きくなり尿道を圧迫する ため排尿障害をきたします。検診では50歳以上の 男性の約 $10 \%$ に治療を要するほどの肥大が認めら れ, 日本全国では 15 万人前後の患者がいると推定 されています。

前立腺肥大症の治療という観点から TUR と開 腹手術を比較してみますと, 麻酔はいずれも腰椎 麻酔や硬膜外麻酔などの下半身麻酔で十分で, 手 術時間も 1 時間から 1 時間半之両者に大差はあり ません．ただ TUR では内視鏡の先端に付いた小 さなループで切除するため, 腺腫が非常に大きい 場合にはやや手術時間が長くなり,ぎゃくに腺腫 が小さい場合にはやや短くなります。経験を積ん だ泌尿器科医が TUR を行った場合 1 分間当たり $1 \mathrm{~g}$ 切除できるのが標準とされており，50g 以上の 腺腫は手術時間が長くなるため合併症を起ししゃ すく, 開腹手術を行う方が安全と考えられます。 術後のカテーテル留置期間は開腹手術では 8 日前 後であるのに対して, TUR の場合には $2 \sim 3$ 日と 短く, 入院期間を短くすることができます. 再発 率は TUR の方がやや高い傾向にありますが, T UR は必要があれば何度でも再手術を行うことが できます.乙うしてみますと, 開腹手術と TUR との間に大きな差はないように思えます。

亿も拘らず TUR が好まれ前立腺肥大症の治療 の主役となった理由は,ひとえに術後傷痕が残ら ないという点にあると思われます。傷痕が残らな いととは minimally invasive surgery の重要な 要件の一つであります。と乙ろが最近になって欧 米では, TUR の術後排尿機能の改善が必ずしも 良好ではないとと, 術後合併症の発生率が決して 低くないとと, 術後 5 年の時点での死亡率が開腹 手術に比べて高いととなどがあい次いで報告され， 
TUR 一辺倒への反省がなされるようになってき ました．また先進国では社会の高齢化に伴い TU $\mathrm{R}$ さえも適応外と考えられる poor risk の患者 が増加する傾向にあり, 保存的療法の開発が強く 望まれる環境にあります，その結果 $\alpha_{1}$ ブロッカー・ $5 \alpha$ レダクテース-インヒビターなどの薬物療法や 温熱療法, 前立腺拡張バルーン・尿道内留置ステ ントなどの新しい方法が試みられ始めており，わ が国でも数年前より導入され臨床的検討が行われ ております。

このように前立腺肥大症の治療の選択肢は, 1990年代に入って飛躍的に増加しており, 今後内 視鏡手術（TUR）は，安全性の向上のためにいく つかの改良が行われるにしても，その占める割合 は次第に縮小の傾向にあるものと思われます。つ まり minimally invasive surgeryから no surgery へと時代が変わりつつあるものと思われます。

内視鏡手術（TUR）を教育という観点から開腹 手術と比較しますと，10年前には TUR をそばで 見て覚えるということはほとんど不可能で, これ が開腹手術に比べて TUR の大きな欠点の一つで ありました. しかし電荷結合型撮像素子（charge coupled device : CCD）を通った色光撮像をコン ピュータ一画像処理し, モニター-テレビに拡大描 出する CCD カメラの登場によってての問題はほ ぼ解決されました。現在は術者を含め複数の人間 がテレビ-モニター上に映し出された同一の画面 で手術の進行を観察でき, 従来ならば 5〜 10年と かかった教育が，2〜3 年で TUR の一応の技術 を習得できるようになりました。

つまり患者側のニーズに応える医者の側の技術 的な裏付けが, 比較的短時間のうちに再生産され るようになったわけです。てれはほかの内視鏡手 術についても言えることで, 新しい技術が広く普 及するための大切な一面であると思われます。

\section{腎孟尿管鏡〔尿路結石の治療〕}

泌尿器科領域において過去10年あまりの間に, 最もいちじるしい変化を遂げたのが尿路結石の
治療であります。乙れは腎孟鏡や尿管鏡といった 上部尿路に対する内視鏡の発達と, 体外式衝撃波 結石破砕という全く新しい概念の導入によっても たらされたものであります.1976年に Fernström ら 'が経皮的に腎瘦を造り，乙れより結石を鉗子 またはバスケットーカテーテルで取り出すことに 成功した三例を報告しました．ただての時はまだ 腎瘻の作成も結石の摘出もレ線モニタ一下に行わ れており, 内視鏡は一切使用されていませんでし た。つで1977年に Kurth ら ’が既存の腎瘻に21 $\mathrm{F}$ の膀胱鏡の外筒を通して, 膀胱結石破砕用に開 発された超音波砕石器で直視下に腎結石の破砕を 初めて行った一例を報告しました。

ここで示された経皮的に腎瘻を造設する, 内視 鏡下に結石を摘出または破砕するというアイデア は，その後1981年になって Alken ら ’方゙経皮的腎 結石破砕を行った34例を報告したことを契機に， 尿路結石治療に革命的な変化をもたらすことにな りました. Alken らは既存の腎瘻を通して結石を 摘出・破砕した15例の他に, 新たにレ線または超 音波モニタ一下に経皮的に腎瘻を造り, 結石の摘 出・破砕を行った19例を報告しました．結石は鉗 子やバスケット・ループなどで摘出した例と, 超 音波や電気水圧衝撃波により破砕した例とがあり ます。これが今日われわれが行っている経皮的腎 結石破砕術 (PNL) の最初の報告と考えられます.

Alken らの報告よりやや遅れて1983年に米国の

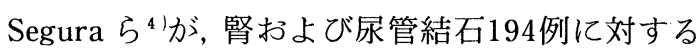
PNL の治療成績を報告しました。バスケットや鉗 子による結石摘出のほかに, 超音波による結石破 砕が行われており，乙れは超音波を使用した結石 破砕の米国での最初の報告であります。乙の報告 によって PNLは開腹手術に代わる新しい尿路結 石治療法として世界的に認知されるに至りました。 そして超音波ガイド下経皮的腎瘻造設術の普及と, 超音波・電気水圧衝撃波・レーザーなどを用いた 新しい結石破砕装置の開発があいまって PNLは 一躍, 上部尿路結石治療の主役となりました。

ところがほほ時を同じくして開発が進められて いた体外式衝撃波結石破砕（ESWL）がすばらし 
い臨床成績をおさめるようになると, 次第に PN L の適応は狭められ, 現在では PNL は珊瑚状結 石に対する ESWL 治療の補助的手段として用い られるに過ぎなくなってきております。まことに 目まぐるしい変化と言えます。

水中衝撃波による尿路結石破砕というアイデア は古く1972年にすでに発表されており，体外で発 生させた衝撃波を収束させて体内の腎結石に照射 し，ヒトの腎結石を破砕することに成功した報告 は1980年に初めてドイッの Chaussy ら ${ }^{51}$ にっ てなされました，当初, ESWL の適応となるのは 径 $2 \mathrm{~cm}$ 以下の腎結石とされていましたが，その 後, 臨床経験の蓄積と共に次第に適応が拡大され, また合併症を防ぐための工夫も進み, 現在ではほ とんどすべての上部尿路結石が ESWL によって 治療可能と考えられております。

しかし ESWL の治療成績を見ますと, 必ずし も $100 \%$ の排石を期待できるものではなく, 平均 的な三力月完全排石率は70\%程度であり，大きな 珊瑚状結石では完全排石率は $50 \%$ に達しないよう です。つまり結石を破砕することはできても, 結 石が完全には無くならない例がかなり存在すると いうことになります。

このような問題点はあるものの, わが国では 1984年にドルニエ社製の ESWL 装置が初めて導 入されて以来急速に普及が進み, 1992年現在で全 国で500台近くの ESWL 装置が稼動していると 言われております，またテレビや新聞雑誌などの マスーメディアを通じての広報活動が盛んに行わ れたとともあって, 今では医療従事者以外の方の 間にも広く情報がゆきわたっており，尿路結石治 療の第一選択としての地位を摇ぎないものとして います。

一方，下部尿路結石に対する ESWL の治療成 績は上部尿路結石ほど芳しいものではなく，下部 尿路結石に対しては次に述べる内視鏡による経尿 道的砕石術がまず試みられます，尿管鏡を用いた 尿管結石の治療の最初の報告は1980年にスペイン の Pérez-Castro ら ${ }^{61}$ にって行われました。こ の時は硬性尿管鏡が用いられています．尿管の
屈曲した走行を考えますと，とても硬性鏡が入り そうには思えませんが，幸い尿管は尿管口を除い て前後左右ほとんど固定するものがないため，比 較的容易に腎盘まで硬性鏡を挿入するてとが可能 です. 次いで Huffman ら”が1983年に硬性尿管 鏡 $(11.5 \mathrm{~F} 12.0 \mathrm{~F}$ channel $5 \mathrm{~F})$ でレ線モニター 下に，5例の尿管結石と 2 例の腎結石を超音波結 石破砕器で破砕した結果を報告しましたが，砕石 時には光学視管を抜いて超音波導子を挿入して行 うため, 直視下の砕石ではありませんでした。そ の後, 1985年に Green $ら^{8}{ }^{8}$ 力硬性尿管鏡 $(9.5 \mathrm{~F}$ $45 \mathrm{~cm}$ channel $5 \mathrm{~F}$ ) で直視下に錙子。バスケッ 卜などで摘出, または電気水圧衝撃波破砕 （electrode $5 \mathrm{~F}$ ) を行った36例を報告したことに よって, 経尿道的結石破砕は本格的な検討の段階 に入り，今日では下部尿路結石治療の第一選択の 治療法となっています。

当初は $12 \mathrm{~F}$ 程度の比較的太い尿管鏡が用いられ たため尿管の拡張が必要であり，乙のため術後に 尿管狭窄をきたす例も決して少なくありませんで した. しかし現在では $7 \mathrm{~F}$ 前後の細い, しかも潅 流チャンネルと操作チャンネルとを備えた尿管鏡 が開発されており，乙のような尿管鏡ではまった く尿管の拡張を必要としません．ただ細径の尿管 鏡を用いる場合には使用できる結石破砕装置が限 定されます．硬性尿管鏡のほかに細径の軟性尿管 鏡の開発も進んでおり, 腎結石の治療にも利用さ れつつあります。

結石破砕には様々なエネルギーが今日用いられ ていますが，砕石しようとする結石の成分・位置・ 大きさなどにより使い分けが必要となります。こ てでその特徴に付いてまとめてみます.

まず超音波ですが一般には50～80 $\mu m$ 程度の低 振幅のものが23〜 $26 \mathrm{kHz}$ の周波数で用いられてい ます，その長所として，プローブ先端が粘膜に触 れても（数秒ならば）ほとんど問題なく，安全性 が高いことが挙げられます。またプローブ内腔を 潅流液が流れプローブの泠却を行うと同時に, 吸 引により砕石片の除去ができるようになっている ことも大きな利点と言えます。超音波の性質上硬 
性鏡でしか使えないことが最大の欠点でしたが, 私自身使用した経験はありませんが, 最近では軟 性鏡でも使用できるワイヤー状のプローブも開発 されているようです.

次に電気水圧衝撃波（EHL）ですが，乙れは水 中スパークにともなう衝撃波のエネルギーで砕石 するものですが，結石を破砕する力が非常に強い ことと, 屈曲可能で硬性鏡と軟性鏡のいずれでも 使用できること，導子が $1.6 \mathrm{~F}$ から $5.0 \mathrm{~F}$ とかなり 細いものまで用意されていることなどがその長所 と言えます。しかしプローブ先端が粘膜に接触し た状態でスパークさせると, 出血や穿孔を起てす ため使用に際して注意を要します。かっては生理 食塩水中では使用できませんでしたが, 最近のも のは使用可能となっています。

現在広く用いられているパルス波色素レーザー 砕石器は, クーマリンという染料の緑色の色素クー マリン-グリーンによって波長504nm の緑色のレー ザー光を発射します．乙の波長は結石のエネルギー 吸収率が高く，かつへモグロビンによる吸収率が 低い特性を持っています. 結石はレーザーのエネ ルギーを吸収すると結石内部に光音響効果が発生 し破砕されます。レーザーはファイバー先端から 出ると急速にエネルギー密度が減衰するととや， パルス波を用いることで非常に高い (100kw) 瞬 間エネルギーを得つつ, 一方で平均エネルギー を低く抑えるてとができるために，組織への熱影 響が最小限に抑えられることなどから周辺組織へ の影響がほとんどない安全性の高い砕石法で, こ れがレーザーの大きな利点と考えられます。現在 レーザー砕石に使用される導光ファイバーの外径 は200・320・550ミクロンの三種類が用意されて おり, $1.9 \mathrm{ch}$ 以上のワーキング-チャンネルを持つ 内視鏡であれば，硬性鏡・軟性鏡いずれも使用可 能となっています、結石破砕のエネルギ一を結石 にまで導く導子を最も細くできるのはレーザ一砕 石器で, 導光ファイバーが細いため内視鏡も細く てよく，尿管結石の破砕でも尿管拡張の必要がまっ たくありません.したがって, 経尿道的結石破砕 にはレーザー破砕器がもっとも適していると
考えられます。しかしレーザー発生装置が5000万 円前後と高価であること, レーザー光が直接目に 入らないように遮光レンズの入った眼鏡をかける か CCD カメラを通してテレビ-モニター上で操 作を行う必要があること, シスチン結石などが壞 れにくいことなどが欠点と言えます。

てのように尿路結石の治療には，内視鏡とさま ざまな物理的工ネルギーとを組み合わせた治療が 広く普及しており, 現在では尿路結石に対して開 腹手術が行われることはほとんどありません，腎 結石は ESWL，尿管結石は TUL が第一選択と 考えられます。

こてで少し視点を変えて, 経済的な面から過去 10年程の間に起こった尿路結石の治療法の急激な 変化を考えてみますと, 体外式衝撃波結石破砕器 （ESWL）は一台数億円もしますし, 先程のレーザー 破砕器にしても一台数干万円します。腎孟鏡や尿 管鏡・腹腔鏡などの内視鏡にしても，七ットとし て揃えるのにそれぞれ数百万円単位の投資が必要 となります。それがしかも数年毎に改良が加えら れ新機種が出現するとすれば, 大学病院や一部の 大病院を除いては，その経済的負担にとても耐え られるとは思われません. 勿論大学病院といえど もその負担が重くないわけではありませんが, 新 しい医療技術の開発という社会的使命を果たすた めに，導入せざるをえないのが実情と思われます。 したがって，てのような経済的な負担が新しい技 術の普及の妨げとなるのではないかとの懸念があ ります。しかし現実には，患者さんの側の侵襲の 少ない治療法への強い欲求に押されて, ESWLの 例をとれば, 日本全国で現在500台近くの破砕器 が稼動しているという過剩配備の状況にあります。 一方で ESWL が設置されていない当院のような 場合には，乙乙数年目に見えて尿路結石の患者さ んの数が減ってきております。また無理をして高 価な機器を購入した施設の中には，その負担が経 営を压迫する例もあると思われます。このような 新しい技術力沃療の現場において効率よく機能す るためには，その適正な配備と十分採算が成り立 つための方策を真剣に考えられなければならない 
と思われます。

\section{腹腔鏡〔精索静脈瘤の治療}

腹腔鏡の歴史は長いにもかかわらず，泌尿器科 領域での応用が始まってからまだ日が浅いと言え ます. Semm が1984年に自動制御の気腹装置を発 明したことと, CCD カメラが1986年に開発され たことは, 腹腔鏡の歴史の上で重大な変化をもた らす出来事でした．事実これを契機として，各臨 床分野においてさまざまな疾患が腹腔鏡手術の対 象として検討を加えられるようになってきました。 泌尿器科においても, 1991年に Clayman ${ }^{9}$ 亿よっ て腹腔鏡的腎摘出術が発表されるに及んで, 今や 開腹手術のほとんどが腹腔鏡下に行われるように なるかの勢いを示しております。現在までに行わ れた泌尿器科領域の腹腔鏡手術としては, 腹腔内 停留睪丸摘出術, 精索静脈瘤に対する内精静脈結 紮術・リンパ節郭清術, 前述の腎摘除術・副腎摘 除術・前立腺全摘術など多岐に瓦っております。 しかしいずれも症例数は少なく，またあまりにも 長時間を要する手術もあり, その臨床的評価を下 すのはまだ時期尚早と思われます。

このような状況の中にあって，比較的手技が簡 単なとともあり，腹腔鏡手術のよい適応として一 般に普及しそうなものに, 精索静脈瘤に対する内 精静脈結紮術があります.

精索静脈瘤は男子不妊症患者の $21 \sim 39 \%$ にみら れ, その場合, 精液所見に精子の形態異常や運動 率の低下を主とする異常がみられる疾患でありま す. 精索静脈瘤の成因としては, 腎静脈血が内精 静脈を経て蔓状静脈丵に逆流䖇滞し, 静脈瘤を形 成することが主たる原因であると考えられていま す.なぜ精索静脈瘤があると精液所見に異常がみ られるのかについては十分明らかにされていませ んが, 精索静脈瘤を外科的に治療するとその55〜 $85 \%$ に精液所見の改善がみられることから，何ら かの因果関係が存在するものと考えられています。 したがって精索静脈瘤の治療は，一般に腎静脈血 の蔓状静脈叢への逆流を防止するために, 内精静
脈を結紮切断する方法が取られます。内精静脈を 切断した場合, 睪丸の静脈血は外精静脈や精管静 脈などの側副路を通ることによりその還流が確保 されます。

現在行われている手術法には開腹手術の他に腹 腔鏡手術と経カテーテル塞栓術があります．腹腔 鏡下の精索静脈瘤手術は1990年に Sanchez-deBadajoz ら ${ }^{10}$ 亿より初めて報告されましたが，そ の手技が比較的簡単なとともあり腹腔鏡手術の良 い適応としてわが国に扔ても急速に普及しつつ あります。通常全身麻酔下に行われますが，局所 麻酔で行われる場合もあります。臍部に腹腔鏡用 の外套管を抢きますと, 両側の内鼠径輪付近は良 好な視野がえられます，操作用の外套管は，恥骨 上約 4 横指の位置と, 臍と内鼠径輪を結ぶ線に対 しててれと対称の位置に置くのが一般的です. 腹 腔鏡による内精静脈の同定は比較的容易ですが, 判りにくい場合には睪丸を牽引することで簡単に 同定できます. 内鼠径輪の $2 \sim 3 \mathrm{~cm}$ 上方で内精静 脈を被う腹膜にT字型の切開を置き, 内精静脈を 動脈より剥離しクリップで結禁後てれを切断しま す. 精巣動脈を一緒に結禁切断しても一般に睪丸 の萎縮は起乙りませんが, その後の妊孕性に多少 差が見られるとの報告もあり, 可能な限り精巣動 脈は温存した方がよいと思われます。手術時間は 1 時間から 1 時間半で, 慣れれば動脈を温存する 術式でも 1 時間以内に手術を終了するととが可能 と思われます，術後鎮痛剂を必要としないことの 方が多く, 術翌日には歩行可能となり, 翌々日に は患者が希望すれば退院も可能です.

この手術に関するかぎり, 早晚開腹手術は無く なるものと思われます。一方, 腹腔鏡手術と経力 テーテル塞栓術との比較は長短甲乙付け難いもの があります. 経カテーテル塞栓術は局所麻酔下に 行える利点がありますが, 内精静脈に選択的に力 テーテルを挿入することはかなりの熟練を要する ものと思われ，腹腔鏡手術の方が手技的にははる かに容易であります。また経静脈的に内精静脈内 にコイルを留置した場合, 動脈ではなく静脈であ るため, これが本来の血流方向に飛んで肺梗塞を 
おこす恐れがないかの不安もあり, また泌尿器科 医ではなく放射線科医の手に治療の主導権が委ね られるなどの点も, 経カテーテル塞栓術の普及の 妨げとなるのではないかと考えられます。したがっ て今後おそらく腹腔鏡手術の方が精索静脈瘤手術 の主流となるものと予想されます。

以上, 三つの疾患を取り上げて泌尿器科におけ る内視鏡の現況について紹介しました. 内視鏡手 術がてれほどまでに隆盛となった背景には, 患者 さんの側の侵襲の少ない治療に対する強い欲求が あります.乙の圧力は外科的治療を開腹手術から 内視鏡手術へ，そしてさらには手術しない治療へ と変えてゆくかもしれません. また医用工学の進 歩はわれわれの予想をはるかに上回るスピードで 進んでおり, 近い将来には精巧な自動制御システ ムの開発によって, 手術手技そのものがコンピュー タ制御された機械（ESWL はそのプロトタイプ とも言えます）によって行われるてとも，あなが ち夢ではないことのように思われます。そうなる と, われわれ泌尿器科医の外科医としての仕事が 無くなってしまうのですが....

\section{文献}

1) Fernström, I., Johanson, B . : Percutaneous pyelolithotomy; A new extraction technique. Scand. J. Urol. Nephrol., 10 : 257 259, 1976 2 ) Kurth, K. H. , Hohenfellner, R., Altwein, J.E.:
Ultrasound litholapaxy of a staghorn calculus. J. Urol., $117: 242 \sim 243,1977$

3 ) Alken, P., Hutschenreiter, G., Günther, R., Marberger, M.: Percutaneous stone manipulation. J. Urol., 125 : 463 466, 1981

4 ) Segura, J. W., Patterson, D.E., LERoy, A. J., May, G. R., Smith, L. H. : percutaneous lithotripsy. J. Urol., 130 : 1051 1054, 1983

5 ) Chaussy, C., Brendel, W., Schmiedt, E.: Extracorporeally induced destruction of kidney stones by shock waves. Lancet, ii : 1265 1268, 1980 6 ) Përez-Castro Ellendt, E., Martinez-Pin̈eiro, J. A.: Transurethral ureteroscopy; A current urological procedure. Arch. Esp. Urol., 33 : 445 460,1980

$7)$ Huffman, J.L., Bagley, D. H., Schoenberg, H. W. , Lyon, E.S.: Transurethral removal of large ureteral and renal pelvic calculi using ureteroscopic ultrasonic lithotripsy. J. Urol., 130 : $31 \sim 34,1983$

8 ) Green, D. F., Lytton, B. : Early experience with direct vision electrohydraulic lithotripsy of ureteral calculi. J. Urol., 133 : 767 770, 1985

9 ) Clayman, R. V., Kavoussi, L. R., Soper, N. J. : Laparoscopic nephrectomy; initial case report. J. Urol., 146 : 278 282,1991

$10)$ Sanchez-de-Badajoz, E., Diaz-Ramirez, F., Vara-Thorbeck, C .: Endoscopic varico-celectomy. J. Endourol, $4: 371 \sim 374,1990$ 